\title{
Steel Specification for the ATLAS Calorimeter
}

\author{
BY \\ VICTOR GUARINO
}

Argonne National Laboratory High Energy Physics Division

Argonne, IL 60439

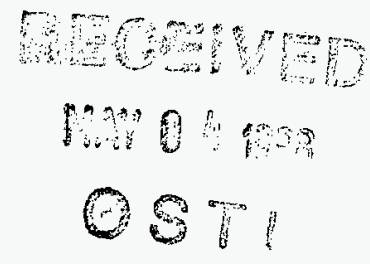

February 10, 1998

DISTRIBUTION OF THIS DOCUMENT IS UNLIMTED by a contractor of the $U$. S. Government under contract No. W-31-109ENG-38. Accordingly, the U.S. Government retains a nonexclusive, royalty-free license to publish or reproduce the published form of this of High Energy Physics, under Contract W-31-109-ENG-38.

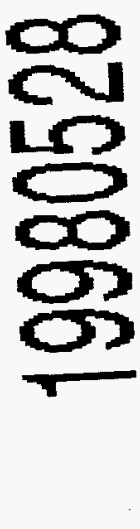

contribution, or allow others to do so, for U. S. Government purposes. 
Argonne National Laboratory, with facilities in the states of Illinois and Idaho, is owned by the United States government, and operated by The University of Chicago under the provisions of a contract with the Department of Energy.

\section{DISCLAIMER}

This report was prepared as an account of work sponsored by an agency of the United States Government. Neither the United States Government nor any agency thereof, nor any of their employees, makes any warranty, express or implied, or assumes any legal liability or responsibility for the accuracy, completeness, or usefulness of any information, apparatus, product, or process disclosed, or represents that its use would not infringe privately owned rights. Reference herein to any specific commercial product, process, or service by trade name, trademark, manufacturer, or otherwise, does not necessarily constitute or imply its endorsement, recommendation, or favoring by the United States Government or any agency thereof. The views and opinions of authors expressed herein do not necessarily state or reflect those of the United States Government or any agency thereof.

Reproduced from the best available copy.

Available to DOE and DOE contractors from the

Office of Scientific and Technical Information

$$
\text { P.O. Box } 62
$$

Oak Ridge, TN 37831

Prices available from (423) 576-8401

Available to the public from the National Technical Information Service

U.S. Department of Commerce 5285 Port Royal Road Springfield, VA 22161 


\subsection{Introduction}

As part of a collaborative experimental High Energy Physics experiment at the LHC Facility, CERN Laboratory, Geneva Switzerland, a group of US institutions has accepted the responsibility for constructing a large portion of the calorimeter for this experiment. This device is referred to as the Tile Calorimeter. The Tile Calorimeter has three major elements, a large center section (Barrel), and two end sections (Extended Barrel). The US group will be responsible for the construction of one of these extended barrel sections. All of the components that are required to construct this device will be fabricated in the US over a period of three years commencing in 1998. Another similar element and the barrel element will be constructed in both eastern and western Europe by parallel groups.

The extended barrel is a cylindrical device approximately 8.5 meters $(28 \mathrm{ft}$.) $\mathrm{OD} \times 4.5$ meters (14 ft.) ID, made up of 64 wedges. Each of these wedges (see Attachment 1 ) is constructed by bolting submodules to a strongback girder. Each submodule is constructed of a series of sheets that are welded and glued together. This document summarizes the characteristics and specifications of these steel sheets.

The Tile Calorimeter is the return path for the magnet flux of the ATLAS internal superconducting $2 \mathrm{~T}$ solenoid, therefore its steel magnetic properties are important.

Details of the construction procedure and the design of the Tile Calorimeter can be found in the ATLAS Tile Calorimeter Technical Design Report (CERN/LHCC/96-42, December 15, 1996).

\subsection{Applicable Documents}

Reference is made in this specification to the documents below:

ASTM A6/A 6M (1996) Specification for General Requirements for Rolled Structural Steel Bars, Plates, Shapes, and Sheet Pilings.

ASTM E45-84 (1984) Standard Practice for Determining the Inclusion Content of Steel

ASTM E112-83 (1983) Standard Method for Determining Average Grain Size

ASTM A370 Test Methods and Definitions

\subsection{Steel Characteristics}

Thirty-eight thousand, six hundred $(38,600)$ sheets of ordinary, low-carbon steel is required for further processing (precision stamping). The size of the sheet required is shown in Attachment 2.

\subsection{Base Material}

Ordinary low-carbon AISI 1010 cold rolled steel is required. The chemical composition of the steel will fall within the following parameters as defined by the AISI standards. 


\begin{tabular}{|c|c|c|}
\hline Element & Minimum & Maximum \\
\hline $\mathrm{C}$ & 0.08 & 0.13 \\
\hline $\mathrm{P}$ & & 0.04 \\
\hline $\mathrm{S}$ & & 0.05 \\
\hline $\mathrm{Mn}$ & 0.30 & 0.60 \\
\hline
\end{tabular}

These analyses refer to the final product. The chemical composition of the steel shall be determined as specified in ASTM A6/6M. In addition, a coupon should be removed from each coil, and a certified analysis of that coupon provided to Argonne National Laboratory as verification of chemical composition. This chemical analysis should also show the level of trace elements $\mathrm{Al}, \mathrm{Si}, \mathrm{Ti}, \mathrm{V}, \mathrm{Cr}, \mathrm{Ni}, \mathrm{Cu}$, and $\mathrm{Mo}$.

\subsection{Production}

The manufacture of the sheet shall occur in accordance to ASTM A6/6M. The manufacturer shall state the method of processing, the method of deoxidation and the type of casting. The sheets shall undergo:

- Hot-pickling

- Acid-pickling

- Annealing in a reducing atmosphere

- Cold-rolled skin pass (0.5-2\% elongation)

- Protection against corrosion using an easily-removable oil

\subsection{Metallurgical Properties}

The steel shall be in the annealed condition and be ferritic-pearlitic. The grain size shall be less than or equal to 50um, measured in accordance with the standard ASTM E112-83.

The inclusions will be measured in accordance to ASTM E45-84, method A. The class of inclusion shall be at most 3 .

\subsection{Magnetic Properties}

The normal magnetic properties of this type of steel will be accepted (magnetic coercivity of 200-250 Am-1). The magnetic coercive forces should be measured transversely and longitudinally to the rolling direction.

\subsection{Material Strength}

The steel should have the minimum yield strength of $27 \mathrm{ksi}(186 \mathrm{Mpa})$ and tensile strength of $50 \mathrm{ksi}(345 \mathrm{Mpa})$ as defined by the AISI standards.

A certification of the material strength is required of each coil. The material strength shall be determined by the methods specified in ASTM A6/6M. All tests shall be conducted in accordance with ASTM A370.

\subsection{Material Thickness}

The sheet thickness that is required is .1969 inch \pm .0010 . The average thickness of a batch (coil), as measured by continuous monitoring at the centerline in the direction of rolling during cold reduction, should deviate no more that \pm 0.0010 inch from the nominal thickness of 
.1969 inch. A copy of the centerline profile measurement taken during the final cold pass on the coil will be furnished to Argonne National Laboratory as part of this contract.

In addition, for each coil, sheets that are cut from the edge of the beginning, end, and middle of the coil will be measured, and these measurements will be recorded. The thickness range within a single sheet must be no more than \pm 0.0012 inch when measured at the twelve points as shown in Attachment 3.

\subsection{Surface Flatness}

Surface flatness for this order is defined as sheet flatness. All sheets supplied as part of this order should meet the following flatness requirement. The maximum deviation from horizontal, when the plate is supported on a flat surface under its own weight, should be no more than 0.029 inch. The out of flatness should be confined to a single node, i.e. ripples in the plate, and will not be acceptable even if it does not exceed the aforementioned 0.029 inch. Argonne National Laboratory reserves the right to reject sheets that do not meet these requirements.

\subsection{Surface Quality}

The surface of the sheets must be free of scale, scratches, lamination defects or rust, and must be protected against corrosion as specified in ASTM A506 and ASTM A6. In the event of surface faults, the results shall be discussed with Argonne and the supplier. The roughness of the sheets shall be no more than RMS 500. Argonne reserves the right to reject sheets that do not meet this requirement.

\subsection{Product Identification and Packing}

Oil that is easily removable shall be applied to both sides of each sheet in order to protect against rust. Approximately 100 sheets will be stacked together on a pallet for shipping. Each pallet of sheets shall be marked in accordance to ASTM A6/6M with:

- Melt number

- Coil number

- Material certification

\subsection{Transportation}

The vendor shall be responsible for shipping the plates to the final destination as specified in ASTM A6/6M and in such a manner as to insure all of the flatness tolerances described above. 


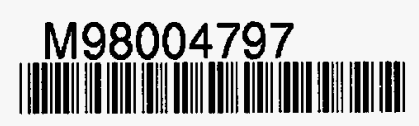

Report Number (14)ANL - HEP-TR - -98-12

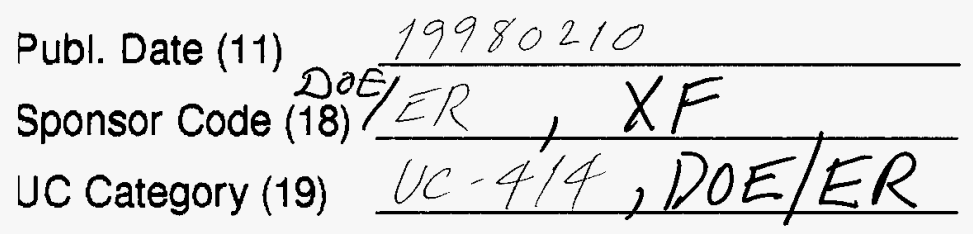

